\title{
SLC43A2 wt Allele
}

National Cancer Institute

\section{Source}

National Cancer Institute. SLC43A2 wt Allele. NCI Thesaurus. Code C118999.

Human SLC43A2 wild-type allele is located in the vicinity of 17p13.3 and is approximately $60 \mathrm{~kb}$ in length. This allele, which encodes large neutral amino acids transporter small subunit 4 protein, plays a role in neutral amino acid transport. 